\title{
Regulatory procedure and participation in the European Union.
}

\author{
Stijn Smismans*
}

(forthcoming in Francesca Bignami and David Zaring (eds) (2016), The Elgar Research Handbook on Comparative Law and Regulation, Cheltenham: Elgar.)

\section{Introduction}

Participation is at the centre of democratic decision-making. In both political theory and public law , the predominance of representative democracy as a normative framework has led to a focus on the legislative process, with the key actors of public rulemaking being conceived of as elected representatives, on the one hand, and 'neutral public officials', on the other. The reality of public policy-making, however, is far more complex, involving actors such as interest groups, civil society organisations, firms, NGOs, and individual citizens long before the idea of 'networked governance' became a popular term in the literature. Yet, on the European continent in particular, public lawyers have paid little attention to such intermediary actors. As their role is not set out in national constitutions, they remain off the radar of constitutional lawyers. At the same time, scholarship on European administrative law has focused on individual rights vis-à-vis the administration rather than on group action in the policy process (Harlow 2006: 120). Rare exceptions have focused on the issue of interest group litigation, rather than on processes of interest representation or lobbying in rulemaking. ${ }^{1}$ The same can be said of the literature on interest group participation in European Union policy-making: there is an extensive political science literature on EU lobbying (Finke 2007; Eising 2008) but legal scholars have shown little interest in the topic, ${ }^{2}$ except for the issue of locus standi in the European Court of Justice (Barnard 1995; Micklitz and Reich 1996; De Schutter 2006). ${ }^{3}$

\footnotetext{
Stijn Smismans is Professor of EU law at Cardiff School of Law and Politics and Director of the Centre for European Law and Governance, the Jean Monnet Centre of Excellence at Cardiff University. The research leading to these results has received funding from the European Research Council under the European Union's Seventh Framework Programme (FP/2007-2013) / ERC Grant Agreement n. 313642-LASI ('Law, science and interests in European policy-making'). I would like to thank Dr. Rachel Minto and Dr. Carlo Petrucci for research assistance.

${ }^{1}$ For an early treatment of the topic in the United Kingdom, see (Harlow and Rawlings 1992).

2 For 'early' exceptions, see Harlow (1992) and Van Gerven (1996).

${ }^{3} \mathrm{~A}$ broader contextual analysis of public interest litigation in the EU is provided by Cichowski (2007).
} 
The virtual absence in legal scholarship of the topic of interest group participation in policy-making can be explained by the neo-corporatist tradition of interest intermediation on the European continent. While the involvement of (mainly large socio-occupational) interest groups in policymaking is institutionalised, particularly via advisory and bargaining structures, it is not proceduralised by giving individuals and groups the right to participate, rights which can be enforced in court via judicial review. Hence, the topic is confined to industrial relations studies, or to labour law studies, in isolation from constitutional and administrative law. This tradition contrasts with the American pluralist tradition in which procedural rights (participation, notice and comment, transparency) and judicial review are thought to ensure a system of interest group competition that plays a central role in a system of checks and balances and democratic and accountable public rulemaking. As a result, legal scholarship in the United States, and administrative law scholarship in particular, ${ }^{4}$ has paid more attention to interest group participation in rulemaking than its European counterpart.

Even in Europe, however, the pressures of modern governance are forcing the legal discipline to reflect more systematically on participation outside of the parliamentary process. Dissatisfaction with representative democracy has led to calls for new governance arrangements in which participation is not limited to the ballot box. As citizens have become more vocal in the information society, additional forms of participation and transparency have become key requirements of modern governance. The wider availability of information has, in its turn, triggered requests for more evidence-based public decision-making, which requires further reflection on the appropriate participatory mechanisms in policy-making characterised by scientific uncertainty. These issues are particularly pertinent in the context of rulemaking beyond the nation state, as it has proven difficult to simply copy traditional models of democracy and institutional design.

In this chapter I will focus on participation in EU rulemaking, which I define to include legislation and delegated legislation. ${ }^{5}$ I will deal with legislation and delegated legislation together, and will thus

\footnotetext{
${ }^{4}$ Going back to early seminal work such as Davis (1969) and Sunstein (1985).

${ }^{5}$ Delegated legislation in the EU has for a long time taken the form of the so-called 'comitology' procedures. Comitology is the process through which a legislative act (most commonly adopted on the initiative of the European Commission and by co-decision by the European Parliament and the Council) empowers the Commission to adopt further regulatory measures but at the same time conditions this delegation by requiring the Commission to interact with a 'comitology committee', composed of representatives from the national administrations, thus allowing the Members States a
} 
not limit my attention to the latter as one would traditionally do in the US when talking about 'rulemaking'. This is for several reasons. Firstly, the type of activity performed via EU delegated legislation does not easily fit into 'our inherited understandings of legislation, adjudication and rulebound administration' (Everson and Joerges 2006: 526) and it is often difficult to draw a clear line between EU legislation and delegated legislation (in particular regarding the subject matter covered by the acts). This relates to the nature of EU policy-making, which is mainly regulatory, while redistributive policies remain the realm of the Member States. Both EU legislation and delegated legislation therefore tend to be rather technical in nature. Secondly, arguments and policy initiatives to strengthen participation in the EU have mainly been made in relation to legislation rather than delegated legislation. This again relates to the particular nature of the European polity. Despite the increased role of the European Parliament (EP) in EU legislation, European policy-making still struggles with a legitimacy deficit (mainly due to the lack of a European public sphere), thus increasing the need to consider all potential sources of 'input-legitimacy', such as interest group participation, even in relation to legislative intervention.

This chapter will thus deal with participation in all forms of European rulemaking leading to binding rules of a general scope. Notwithstanding the EU's large, and growing, number of institutional arrangements and policy instruments, lawmaking and delegated lawmaking spearheaded by the Commission remain the most important forms of governance in the EU. As a result, given the space constraints, this chapter will focus on participation in Commission decision-making and will not consider participation in other forms of EU decision-making (see Hofmann in this volume), such as the decentralised networks of European Agencies (which, unlike agencies in the US, have a mainly knowledge-gathering rather than a rule-making role) ${ }^{6}$ or participation in soft-law benchmarking procedures, such as the Open Method of Coordination. ${ }^{7}$ The chapter is also limited to rulemaking at the EU level, and will not cover the EU's impact on participation arrangements at the national level,

degree of control over the supranational Commission. The system has been revised by the Lisbon Treaty, as will be explained in section 4.1 .2 below.

${ }^{6}$ For an overview of the European agency debate, see Rittberger and Wonka (2011) and Busuioc, Groenleer and Trondal (2012).

${ }^{7} \mathrm{EU}$ official documents have often stressed the benefits of broad civil society participation in the Open Method of Coordination (OMC), and some scholars have heralded the $\mathrm{OMC}$ as an example of participatory experimentalist governance. See Gerstenberg and Sabel (2002) and Sabel and Zeitlin (2008). Others have questioned the bottom-up participatory credentials of the OMC and new modes of governance more generally. See Smismans (2008). 
such as via the Aarhus Convention. ${ }^{8}$ Finally, I will deal with the role of interest groups as policy advocates in rulemaking, not with their role as service providers in policy implementation nor with the self-regulatory schemes developed and administered by different socio-economic groups.

The chapter is structured as follows. In section 2, I analyse how the European neo-corporatist tradition influenced the EEC/EU's initial approach to interest group participation in policy-making. These formal institutional arrangements, however, were quickly paralleled by a more informal pluralist practice as a consequence of the multiple access points that characterise EU policy-making as well as the dispersed character of the interest group field at the EU level. This pluralist practice is not proceduralised and does not provide for participatory rights and judicial review as is characteristic of pluralist institutional design in the U.S.. In section 3,1 examine how the EU, since the mid-1990s, has started to address the issue of interest group participation more explicitly, as a result of both a (perceived) need to increase the legitimacy of its policy-making and the need to provide an institutional response to the increasing pluralisation of interest groups. The EU's answer has been to resort to the concept of civil society, and to provide for 'pluralisation without proceduralisation', which has focused much more on the legislative process rather than on delegated legislation. In the last section, I focus on three major debates that have characterised the EU over the last decade and which have (theoretically) the potential to move EU interest representation more in the direction of the American pluralist model: the changes introduced by the Lisbon Treaty (and in particular its new system of delegated legislation); the better regulation debate; and the European Transparency Initiative. Nevertheless, I conclude that although the 'traditional' neo-corporatist design is ever more under threat, the EU's approach remains one of 'pluralisation without proceduralisation' (one which is gradually being extended to delegated legislation) and judicial review initiated by interest groups continues to be viewed as a fairly marginal device for ensuring balanced representation in policy-making.

\section{The EU between European neo-corporatist inspiration and informal pluralist practice}

\subsection{The European neo-corporatist tradition}

\footnotetext{
${ }^{8}$ The UN Aahrus Convention has been translated by the EU in two Directives and one Regulation dealing respectively with national and European level participation and transparency in environmental matters, see http://ec.europa.eu/environment/aarhus/legislation.htm .
} 
The system of interest group participation in policy-making in Western European countries has a long neo-corporatist tradition. Neo-corporatism has been described by political scientists (Schmitter and Lehmbruch 1979; Lehmbruch and Schmitter1982; Cawson 1986; Williamson 1989) as a system of interest intermediation in which a limited number of rather encompassing socio-occupational organisations (particularly trade unions and employer organisations) obtain a privileged role in policy-making. Tripartite negotiation (between government, trade unions and employer organisations) characterises central government policies, while trade unions and employer organisations often deal with more specific socio-occupational issues in an autonomous, selfregulatory way via bipartite bargaining. The model depends on the existence of strong trade unions and employer organisations, which are representative of their sectors and which are in a position to ensure the acceptance of negotiated central bargains by their members. It equally depends on a relative balance of power between trade unions and employer organisations. To ensure this type of balanced system of strong organisations, the state takes on an active role, both supporting these organisations and creating an institutional framework to involve them in decision-making. With the exception of the right to strike, however, the system is based on a balance of countervailing bargaining powers rather than on a set of detailed participation rights subject to judicial review. Neo-corporatism developed post-World War II and goes hand in hand with the development of the welfare state and central policy intervention focused on socio-economic as well as industrial policy.

The European neo-corporatist tradition has often been defined in contrast to the American pluralist tradition (Wagner in this volume). As early as the 1950s, authors such as Truman (1951) and Dahl (1956 and 1961) described the American polity as a process in which interest groups struggle for influence. Characteristic of their pluralist model is the division of power between different power centres, creating multiple points of access for a large number of interest groups. The state tends to be placed in a passive role, registering the demands of group interests. ${ }^{9}$ Though the early American pluralists such as Truman and Dahl called themselves 'empirical democratic theorists' (Held 1996: 199), ${ }^{10}$ they tended to legitimate or even glorify (Hyman 1978: 18; Nino 1996: 82) the system of

\footnotetext{
${ }^{9}$ 'Government is [...] the target for group activity, and the arbiter of group demands, but its role is responsive. Governments do not create or fashion interests...', Cawson (1986: 47).

${ }^{10}$ Their stated aim was to highlight how classic democratic ideals and theoretical conceptions of representative government failed to capture the way in which politics really worked (Held 1996: 199).
} 
group competition as the best way to come to a democratic equilibrium in society. ${ }^{11}$ Their model has also been called 'interest group liberalism' since the democratic equilibrium is supposed to be the outcome of an unregulated process. State intervention is minimal and individuals are conceived as utilitarian satisfaction-maximisers (Cohen and Rogers 1995: 13). Contrary to utilitarian theorists, however, pluralists contend that the best way to maximise satisfaction is for individuals to organise into groups to pressure government on issues of concern to them. If people fail to organise and to participate in politics they can be assumed to be satisfied with the policy output. It is also argued that because of the multiple access points to government and the tendency for individuals to have overlapping memberships in different organisations, no group can become dominant over others. Consequently, the 'general interest' is but the automatic outcome of interest group competition. ${ }^{12}$

The normative assumptions of this model of 'interest group liberalism' have been seriously challenged, most notably in the work of Mancur Olson (1965), ${ }^{13}$ which made clear that unregulated group competition could not lead to an automatic democratic equilibrium, given the inequality of resources of interest groups. The response, in public law, was to proceduralise processes of representation and bargaining, to ensure that all interests would have an equal chance of being heard and influencing outcomes. ${ }^{14}$ The history of American constitutional and administrative law, and especially of judge-made public law, is characterised by this attempt to ensure equal access to policy-making by building on the principles of transparency and 'due process' (Shapiro 1988: 36; Stewart 1975; Sunstein 1985; Craig 1990: 56). Both legislatures and bureaucrats are required to take into account the variety of concerned interests in policy-making, and are subject to review by the judiciary for compliance with these requirements, though with considerably more rigour for

${ }^{11}$ It should, however, also be noted that in certain cases later 'neo-corporatist authors' straw manned the pluralist model, making it easier to criticize (Nedelmann and Meier1979: 94).

12 The only value transcending the private interests of groups is an assumed 'community of purpose'-, a consensus about the rules of the game, i.e. everybody accepts that interest-group competition generates the 'general interest' (Lowi 1969: 294).

${ }^{13}$ Olson (1965) pointed to problems such as 'free-riding': a common interest shared by a large aggregate of individuals will have difficulties influencing policy-making because people do not organise when they think they profit from the action of others. Conversely, interests shared by a small group will strongly influence government because of the greater incentives to organise.

${ }^{14}$ Cohen and Rogers (1995: 28) therefore talk about 'egalitarian pluralism'. 
administrative than legislative decision-making (see Sunstein 1985: 65). ${ }^{15}$ With respect to administrative rule-making, the Administrative Procedure Act (APA) requires a notice and comment procedure which obliges an agency to give notice that it is contemplating a rule, receive comments from interested outsiders, print its final rule in the Federal Register and accompany the published rule with a concise and general statement of its basis and purpose (Wagner this volume). For the adjudicative decisions of agencies, the APA provides for trial-like procedures. ${ }^{16}$ The way in which administrative law has intervened to ensure due process for individuals and groups is at once a departure and a continuation of the initial pluralist idea of interest group liberalism. On the one hand, it requires legal intervention to ensure 'fair' interest group competition. On the other hand, the focus is on creating formal equality in the legal opportunity to participate, leading potentially to an imbalance between those with enough resources to use the legal channels (repeatedly) and those without such resources (Wagner this volume). With its emphasis on formal equality, the model stays loyal to its original underpinnings (and contrasts sharply with the neo-corporatist starting point), namely that the state should not actively intervene to facilitate the organization of civil society or to create representative settings, as interest group competition will ensure the emergence of the public interest in a system of checks and balances. ${ }^{17}$ As Bignami (2011) argues, this difference between the American pluralist model and the European neo-corporatist model links to broader political cultural differences in how the relation between the state and society is conceptualised, with the European tradition more open towards State intervention to ensure the public good, and the American one more inclined to rely on competitive processes. ${ }^{18}$

${ }^{15}$ The underlying idea is that in reviewing legislative action, especially when the relevant questions concern the motivations for such action, courts ought to give legislators every benefit of the doubt.

${ }^{16}$ On the pro-active role of the judiciary in formulating ever more demanding requirements for equal access to processes of administrative adjudication and rule-making, and even legislation, see Shapiro (1988), Sunstein (1985) and Stewart (1975). This tendency reached its apogee in the early 1980s when disillusionment with the 'almost frantic pursuit of more and more perfect pluralism' set in (Shapiro 1988: 49).

${ }^{17}$ The U.S. has experimented with more consensual forms of interest consultation, for instance, the committees established pursuant to the Federal Advisory Committee Act, and negotiated regulation, but they have remained at the margins of a system that is mainly based on interest competition via the notice and comment process (see Wagner this volume).

${ }^{18}$ This is also related to differences in legal culture, with the American legal system relying more on 'adversial legalism' and the European one placing more trust in bureaucratic decision-making (Kagan 2007). 
The European neo-corporatist alternative to pluralism has been in decline since the 1980s for multiple reasons. Due to the pluralisation of society and the labour market, people identify with a wider variety of functional groups and not necessarily with big encompassing organisations of management and labour. At the same time, government intervention today extends to a wide array of new regulatory areas (environment, consumer, public health, research \& innovation, and so on), in which management and labour are not necessarily the best informed interest groups or those with the highest stakes. By the same token, those areas of socio-economic governance such as industrial policy and labour market protection, and, more recently, welfare policy, which directly implicate neo-corporatism have been pushed back by neo-liberalism and globalization, trends which have also undermined a key component of the model, namely the organisational capacity of labour. That being said, more decentralised, multi-level, and slimmed-down versions of neo-corporatism continue to operate in several European countries, ${ }^{19}$ often allowing for more egalitarian policyoutcomes less prone to changes in the economic growth cycle. ${ }^{20}$ While trade unions have nowhere near the organisational capacity they had in the past, the neo-corporatist legacy continues to shape in important ways state-society relations and institutional approaches to interest intermediation.

2.2. The impact of the neo-corporatist tradition on the EU: institutionalisation without proceduralisation

Moving from the national level to the EU, the European neo-corporatist legacy has also influenced the way in which interest group participation is organised within EU policy-making. At the creation of the European Coal and Steel Community in 1951 it was considered indispensable to involve the social partners in the new supranational organisation, given their central role at the national level in

\footnotetext{
${ }^{19}$ Updates on the neo-corporatist model can be found both in the literature on comparative industrial relations (e.g. Crouch (1993) and European Foundation for Living and Working Conditions (2013)) and in the varieties of capitalism literature, in which the relationship between interest groups and the state constitutes one of several dimensions of political economy that together result in different models of capitalism or models of welfare states, e.g. Esping-Andersen (1990) and Ebbinghaus and Manow (2001).

${ }^{20}$ While the economic crisis that started in 2008 has accelerated the trend towards decentralisation of industrial relations, those countries with the most developed industrial relations systems have been able to cushion their economies better from the negative impacts of the crisis (Hyman 2010; Glassner, Keune and Marginson 2011).
} 
this area. Consequently, the High Authority, the predecessor of the European Commission, included persons close to or emanating from the trade union movement (European Trade Union Institute 1990: 44). In addition, to assist the High Authority, a separate Consultative Committee was created, composed of representatives of producers, workers, consumers and traders. ${ }^{21}$

A similar approach was subsequently followed for the European Economic Community at its creation in 1957. All founding Member States, except Germany, ${ }^{22}$ had economic and social councils at the national level and favoured the creation of such a council at the European level. The European Economic and Social Committee (EESC), composed of representatives from national sociooccupational organisations (trade unions, employer organisations and professional associations), was set up with an advisory function similar to that of the European Parliamentary Assembly. The creation of the EESC should be placed within the context of the sector-by-sector approach to European integration (Lodge and Herman 1980: 267). The 'Monnet method' (Featherstone 1994: 155; Wallace 1996: 42) was based on the involvement of key economic elites, including organised labour, in each of the particular sectors targeted for integration on the theory that they would build transnational coalitions in support of European policies (Wallace 1993: 300). The first Commission (and the High Authority in the ECSC) did not bring proposals to the Council without having first obtained the agreement of interest groups at the European level (McLaughlin 1985: 164), and it was in particular hrough the EESC that these interest groups were represented. ${ }^{23}$ It has even been argued that the agreement reached among the socio-economic interests in the EESC carried greater weight than the opinion of the Assembly, since, during the initial period, it was composed of leading personalities from well-established socio-economic organisations, whereas the Assembly was still a non-directly elected body (Corbey 1996: 346).

\footnotetext{
${ }^{21}$ On the creation and the first years of this Committee, see Mechi (2000).

${ }^{22}$ Germany's reluctance was due to its experience with corporatist institutions under Fascism. For purposes of the discussion in this chapter, however, it is important to keep in mind the difference between 'authoritarian corporatism' (through which authoritarian regimes were linked to economic elites, while at the same time fake trade unions were used to control labor) and 'societal' and 'liberal' corporatism, which developed later (hence 'neo-corporatism') and in which trade unions and employer organisations operated as free organisations and were guaranteed autonomy from the state (Schmitter 1979).

${ }^{23}$ On the attitude of the first Commission president, Walter Hallstein, see Lodge and Herman (1980: 269).
} 
However, as the EEC, and then EU, engaged in increasingly more policy areas, the EESC lost much of its appeal (Smismans 2000). First of all, being composed of representatives from national sociooccupational organisations, it could not provide a forum for traditional tripartite corporatist bargaining between key representatives of broad, encompassing organisations capable of committing their organisations. Moreover, as the EU became involved in more regulatory fields, the socio-economic focus of the EESC prevented it from representing the diversity of interests and expertise implicated by the expanding agenda. Hence interest groups increasingly lobbied directly the European Commission, Council and European Parliament (in the case of the latter, as its powers began to increase) and established offices in Brussels which could serve as a base for these lobbying efforts. Many political scientists have therefore described the system of interest intermediation in the EU as pluralist. This pluralist system is defined by two principal characteristics: (1) it involves a diverse and large set of interest groups (European and national associations, as well as individual firms and consultancies) rather than a limited number of encompassing and representative associations; (2) the policy-making process contains many points of access, both through the multiple institutional players at the European level and through the national politics of the Member States (Streeck and Schmitter 1991; Schmidt 1997).

Notwithstanding these developments, it is important to appreciate the continuing influence of the neo-corporatist underpinnings of the EU's system of interest intermediation. First, in the field of European social policy, since the mid 1980s the EU has developed the European social dialogue procedure, which copies the neo-corporatist model of some of its Member States. The European Commission is obliged to consult the Europe-wide federations of national trade unions and employer organisations on all of its legislative proposals in the area; these federations can decide to take on the issue themselves through bipartite negotiation (collective agreements), sidestepping the Commission and the other EU institutions, and their collective agreements can be given legal, binding force. Although the scope of the social dialogue is limited to the field of social policy, and its results have been modest, ${ }^{24}$ it follows a traditional, neo-corporatist design.

Second, and more important for this analysis, while from the perspective of political science the pluralist label may better capture informal lobbying practices in the EU, the characterization is less apt from a legal perspective focused on institutional design and its impact on interest group participation. As discussed earlier, in the U.S, the procedural guarantees of administrative law have been shaped by the pluralist idea that free interest group competition plays a central role in the

\footnotetext{
${ }^{24}$ For an overview of the European social dialogue, and the EU's role in industrial relations more broadly, see Smismans (2012).
} 
definition of the public good and in the control of government power in a system of checks and balances. Transparency, access to documents, and notice-and-comment procedure allow all stakeholders (or at least those with enough resources to organise effectively) to participate in rulemaking, with access to judicial review as an oversight mechanism. This system of pluralist proceduralisation is foreign to the EU. Instead, the institutionalisation of interest group participation in the EU displays more neo-corporatist features.

A key element of this neo-corporatist design is the institution of advisory committees. Advisory committees have existed since the creation of the EEC and have multiplied over time. They are generally specific to a policy field or policy problem and can provide the EU institutions, and the European Commission in particular, with far more in-depth expertise and representative positions than the 'generalist' EESC. These advisory committees or expert groups ${ }^{25}$ can be composed of 'independent' scientific experts, of representatives from national administrations, of interest groups, or a combination of the three. ${ }^{26}$ The European Register of Expert Groups today lists 832 expert groups, ${ }^{27} 503$ of which include representatives of interest groups, and 142 of which are exclusively composed of such groups. Advisory committees can be set up formally, i.e. by a Commission decision, but more often they are created informally by a Commission unit. Some committees have a role in the drafting of legislation and/or delegated legislation, while other are involved in policy implementation. Some are permanent, while others are 'ad hoc' created for a single policy initiative. Except for some cases where the creation of such a committee is required by legislation, the establishment as well as the composition of such committees is at the discretion of the Commission. To constitute a committee, the Commission Directorate General (DG) in the relevant policy area may use a 'public' call for experts on its website but may also simply rely on its existing informal networks or ask Member States to propose experts. Equally, it is entirely within the discretion of the Commission DG whether it will take into account the opinion of such a committee.

For a long time, these committees have functioned completely outside of public view. There was no transparency on the exact number of committees or their composition. Today, the Commission's online Register of Expert Groups aims at providing an overview of all advisory committees, as well as

\footnotetext{
${ }^{25}$ The Commission traditionally called them 'advisory committees', but has more recently shifted to the term 'expert groups'. In this discussion, I use the two terms interchangeably.

${ }^{26}$ For an overview of the types of expert committees and their functioning, see Larsson and Murk (2007: 94)..

${ }^{27}$ Please see, http://ec.europa.eu/transparency/regexpert/index.cfm, last accessed on 16/08/14.
} 
their composition. ${ }^{28}$ However, the Commission does not publish general calls to fill positions on advisory committees and does not invite comment on the proposals. Neither are opinions of expert groups systematically published. This system of interest intermediation, therefore, operates very differently from the proceduralised American system and appears to be inspired more by the European neo-corporatist tradition. While EU administration has ample discretionary powers, it is, at least in theory, to be guided by the objective of involving the key (preferably representative) actors in the field. These actors are brought together in a committee and are expected to discuss or negotiate in order to produce a common position. While the criteria for selecting committee members are rarely made explicit, advisory committees are generally constituted with the ambition of generating a representative 'European view', and to that end often include representatives from all Member States (either from national administrations or interest groups) or from Europe-wide associations (which tend to be confederations of national interest groups). In many cases, the Commission has also privileged such European organisations when informally sounding out the public and gathering information on policy initiatives. Moreover, it has created several funding programmes and budget lines to support the creation and development of Europe-wide associations (Mahoney and Beckstrand 2011), in particular those representing non-profit, 'weaker' (e.g. trade unions) or 'public interest' (e.g. environmental, consumer, social inclusion...) sectors. This active support for civil society organisations even extends to financial assistance for such organisations at the national level in countries where intermediate organisations are poorly established, particularly in Central and Eastern Europe after communism, on the theory that weak national organisations undermine the representativeness of confederal associations at the European level (Pérez-Solórzano Borragán and Smismans 2012).

Taken together, the EU's system of interest intermediation can be conceptualized as 'neocorporatist in inspiration combined with informal pluralist practice'. The use of advisory committees that aim at some level of representativeness and deliberate or negotiate common positions, as well as active financial support for the development of civil society organisations bear witness to the neocorporatist legacy. At the same time, EU institutions have not closed their doors to informal lobbying, which is 'pluralist' both in terms of the diversity of the interest groups involved and the number of access points. Although this system is institutionalised, it does not follow the proceduralised, pluralist template of U.S. law: it is not transparent, it lacks participation rights, and it limits judicial review of the process of rule-making. With respect to legislative action, whether and

\footnotetext{
${ }^{28}$ There are no data available on whether the Register is in reality exhaustive, given the informality of some of the advisory committees. However, publication of the existence of a committee has become the norm the Commission intends to follow. Information on the composition relates to the organizations represented rather than to the individuals composing the committee.
} 
how to use advisory committees lies entirely within the discretion of the Commission and other institutional actors. With respect to delegated legislation, there is the possibility of obtaining judicial review of the process in those cases in which the legislation delegating regulatory power requires the Commission to consult an advisory committee (or interact with a so-called 'comitology committee' composed of representatives from national administrations). If the Commission fails to engage in consultation, it can be taken to court, but this type of explicit consultation requirement is the exception rather than the rule and, in any event, neither the advisory committee nor any interest group (represented or not on the committee) would have the right to contest a final legal act because of a failure to take into account their opinion.

It is beyond the scope of this analysis to draw any comparative conclusions on whether this European system of 'neo-corporatist inspiration with informal pluralist practice' would score better or worse in terms of 'fairness' than the American proceduralised pluralist model. In some of the more recent literature, this system has been said to generate policy-learning (Knoepfel and KisslingNäf 1998), or even constitute a form of deliberative democracy (Habermas 1996; Elster 1998; Bohman and Rehg 1997; Dryzek 2000) at least to the extent that 'interests' are not set in stone and the positions of committee members are constituted through deliberation. The link, however, between the reality of committee governance and theories of deliberative democracy is problematic since the current process is opaque and does not appear to be linked to deliberation in the wider public sphere. While this lack of transparency may not have been objectionable in traditional neocorporatism, since officials from broadly representative social partner organisations ultimately had to defend the outcomes of committee bargaining to their memberships, the difficulty of establishing such organisations today, especially at the European level, makes it more suspect. Thus, even though advisory committees have the potential to provide a forum for deliberation among representative organizations and even though the Commission has made an effort to bolster the organizational capacity of certain diffuse interests, there is also evidence of cases in which advisory committees do not offer a 'fair' representation of interests.

One indication of this representational imbalance can be found in the results of an inquiry led by ALTER-EU (Alliance for Lobbying Transparency and Ethics Regulation in the EU), ${ }^{29}$ an association of about 200 civil society organisations, trade unions, academics and public affairs firms. ALTER-EU argues that roughly 100 of the 832 or so expert groups in existence today are dominated by large corporations, especially in key policy areas such as the Internal Market, Agriculture, and Enterprise

${ }^{29}$ Please see, www.alter-eu.org, last accessed on 16/01/14: 
and Industry. ${ }^{30}$ One of the culprits of this outcome is the absence of clear rules on 'conflict of interests', which enables individuals working in or for private companies to regularly register as individual independent experts rather than as representatives of an interest group when they serve on expert committees. In sum, it is unlikely that the system of (neo-corporatist) EU expert committees can fully compensate for the imbalances of free interest competition in (pluralist) EU lobbying. Whether the American proceduralised system, with formal, equal participation rights and extensive judicial review, but significant informal inequalities, would score any better in terms of fairness is another question (Wagner in this volume).

\section{Reconciling European tradition with further pluralisation? 'Pluralisation without proceduralisation'}

\subsection{Transparency: 'pluralisation without proceduralisation' (the pluralist way)}

Despite the proliferation of both informal lobbying and advisory committees, the EU did not adopt a horizontal approach to interest group regulation until the early 1990s. The system remained opaque and ad hoc, with no coordinated practices in the different Directorates General of the Commission. With the Maastricht Treaty, however, which extended the EU's competences considerably and was expected to generate a commensurate proliferation of EU interest group activity, the Commission was prompted to develop a more comprehensive policy on how it would interact with the public. It did so in 1992, in two related communications adopted on the same day. ${ }^{31}$ The first communication promised that the Commission would improve its efforts to make policy proposals publicly available in an explicit attempt to invite contributions from interest groups. The second communication addressed more directly the issue of interest group participation. The Commission announced that it would create a Single Directory of the interest groups with contacts with the Commission, which would supplement the existing, uncoordinated system of separate lists in each Directorate General (DG) and would streamline the process of interacting with interest groups. It also intended to tackle problematic lobbying practices by inviting interest groups to sign a voluntary code of conduct.

The normative inspiration of the approach put forward in the 1992 communications was pluralist. The Commission explicitly praised the added value of interest group activity as providing the

\footnotetext{
${ }^{30}$ ALTER-EU, Statement on the new framework on experts, 10 January 2010.

${ }^{31}$ Commission, "An open and structured dialogue between the Commission and special interests groups" [1993] OJ C63/02, and Commission, "Increased transparency in the work of the Commission", [1993] OJ C63/03.
} 
administration with valuable expertise. The objective was not to shape directly the relationship between administration and interest groups but to improve the transparency of the Commission's work, so as to facilitate the participation of interest groups. As long as the Commission provided more information on its proposals, free interest group competition would guarantee that it would obtain the necessary policy information. 'In exchange' for improved contacts with the Commission, interest groups were simply asked to abstain from unfair lobbying practices. And even this minimal attempt to regulate interest group activity was entirely voluntary, and, in fact, only a minority of interest groups signed codes of conduct.

To summarize, the Commission's initiative at the start of the 1990s sought to facilitate broader involvement in informal lobbying by making a number of changes to institutional practice that would sit on top of the existing (unchanged) system of advisory committees. It did so through 'pluralisation without proceduralisation': the two communications were soft law documents, which implied that the promise to make the Commission's work more transparent did not carry any rights to participation or to judicial review.

\subsection{Civil society: 'pluralisation without proceduralisation' (the neo-corporatist way)}

By the end of the 1990s-early 2000s, the paradigm at the heart of the Commission's approach to interest groups shifted dramatically, at least in the discourse employed in the Commission's official publications. At the time, the Commission was responding to at least two developments in the broader political environment. First, despite the increased role of the European Parliament in European decision-making, and the efforts in the Amsterdam Treaty to address the EU's 'democratic deficit', the EU was continuing to struggle with a legitimacy deficit. Second, the protests of the 'no global' movement had brought increased public attention to the role of NGOs in international governance. It was in this context that the Commission's approach to interest groups began to be framed by the concept of civil society.

The Commission's paradigm-shift first came to light in the area of social policy. On issues such as anti-discrimination, gender policy and social inclusion, the traditional social partners had been sidelined by a number of newer interest organizations with a more direct stake in the policy issues. The Commission recognized this reality by promoting, alongside the social dialogue with the social partners described earlier, a 'civil dialogue' with these civil society organisations. The civil dialogue did not provide the involved organisations with powers comparable to those of the social partners in the social dialogue; instead, it took the form of regular forums with such associations (representing 
both the national and European levels) and even more regular meetings with representatives from the Europe-wide associations. Similar initiatives were taken in areas such as the environment, public health and (following the no global protests) trade. Hence, in several areas, extra attention was paid to including 'weaker' and 'general interest' groups in the policy-making process (as opposed to better-resourced business and private interest groups).

These sectoral developments were followed by the Commission's general statement on 'civil society' in its White Paper on European Governance (2001). In contrast with the concepts of 'interest groups' and 'lobby groups', which often invoke suspicion, the Commission's use of the term 'civil society' signalled the democratic potential of bottom-up participatory processes. According to the White Paper, civil society organisations included not only 'NGOs but also trade unions and employers' organisations, professional associations, charities, grass-roots organisations, organisations that involve citizens and local and municipal life with a particular contribution from churches and religious communities'. ${ }^{32}$ Although this definition was not comprehensive, it did imply that civil society organisations were more representative than other interest groups. The White Paper, therefore, set out a two-track model of consultation: on the one hand, a set of common standards and principles for the consultation of all 'interested parties', and on the other hand, the development of 'more extensive partnership arrangements' with more representative civil society organisations.

By endorsing a special relationship with more representative civil society organisations, the White Paper suggested a pluralisation of the neo-corporatist method. To quote directly from the White Paper:

On the Commission's part, this will entail a commitment for additional consultations compared to the minimum standards. In return, the arrangements will prompt civil society organisations to tighten up their internal structures, furnish guarantees of openness and representativity, and prove their capacity to relay information or lead debates in the Member States .... With better involvement comes greater responsibility. Civil society must itself follow the principles of good governance, which include accountability and openness.

Just as social partners had been granted privileged access because of their representative nature, new civil society organisations in pluralised contemporary society, such as environmental or

\footnotetext{
${ }^{32}$ Communication from the Commission of 25 July 2001 "European governance - A white paper", $\operatorname{COM(2001)} 428$ final - Official Journal C 287 of 12.10.2001.
} 
consumer groups, were to benefit from closer involvement as long as they were non-profit associations representative of broader interests.

It is clear, however, from a review of the recent history, that the Commission has failed implementing this stated commitment to a special relationship with civil society organisations. The key instrument was to be a public database of European civil society organisations (CONECCS). The database was to provide Commission officials with a clear list of 'more representative organisations', while for civil society organisations it was to 'act as a catalyst to improve their internal organisation.' CONECCS, however, has failed to fulfil these ambitions. The criteria to be eligible for the database were not demanding: listed organisations had to be non-profit associations with the mission of representing their members, be organised at the European level, i.e. with member organisations in at least two EU countries, be active and have expertise in one or more of the Commission's policy areas, and have some degree of formal or institutional existence. These requirements fell far short of the hard representativeness requirements that are still used in many European countries, in particular in the industrial relations field, such as a minimum number of members and formal conditions on how the organization is to guarantee the authority and accountability of individuals designated to speak for the organization. Even more important, the Commission failed to develop 'extensive partnership arrangements' that would incentivize organizations to register with the database and meet the admittedly minimal criteria required for registration. Vice versa, Commission officials had little reason to pay more attention to CONECCS organisations since registration did not provide much of a guarantee of their representative quality. In sum, despite the strong rhetoric in both EU official documents and the academic debate, the civil society concept seems to have had relatively little influence on the actual consultation practices of the Commission. ${ }^{33}$

The first of the two consultation tracks proposed in the White Paper-consultation of all 'interested' parties--has had a more significant impact. In 2002, the Commission adopted a communication spelling out in more detail the procedure to be followed, called the General Principles and Minimum Standards for Consultation of Interested Parties. The Principles include: wide participation throughout the policy chain, in particular regarding major policy initiatives; effectiveness, which implies consulting as early as possible but also in a manner proportionate to the impact of the proposal; coherence as between Commission departments in how they conduct consultations;

\footnotetext{
${ }^{33}$ As described earlier, there was change, but mainly through the increased use of forums for European civil society organisations at the sectoral level, not in the cross-cutting fashion advocated in the White Paper.
} 
openness; and accountability. The Standards require that the Commission provide clear information on the content of the consultation and the procedure to be followed, that it announce the consultation on the internet via the single access point Your Voice, that it allow at least twelve weeks for interest groups to submit their opinion, and that it acknowledge receipt of opinions as well as provides 'adequate feedback'. Since the early 2000s, the Commission has conducted numerous consultations along these lines.

These Principles and Standards suggest a proceduralisation of Commission consultation practices but in actual fact the proceduralisation that has occurred has been quite limited and 'soft.' A number of factors have contributed to this result. First, the requirements are set down in a nonbinding Commission Communication and are phrased so as to leave the Commission with considerable discretion. As a result, they cannot be relied on in court, except as an interpretative tool in the application of other, binding procedural provisions (in those few case where such provisions are available), and can generally only be used to challenge administrative practice via the softer mechanism of the European Ombudsman. Second, the scope of the Principles and Standards is so ambiguously framed as to avoid tying the hands of the Commission in most cases, with the result that the decision to go ahead with a consultation is generally entirely within the discretion of the Commission. Third, the Communication does not extend to all of the Commission's consultation mechanisms. The Commission states that it will 'focus on applying the general principles and minimum standards to those initiatives that will be subject to an extended impact assessment' and to Green and White Papers. Explicitly excluded are the social dialogue, delegated legislation, ${ }^{34}$ and more generally all consultation mechanisms set out in the Treaties or in other Community legislation. Most institutionalised consultation mechanisms thus fall outside of the application of these general principles and standards. In sum, the Principles and Standards apply mainly at the

\footnotetext{
${ }^{34}$ The text refers to excluding 'comitology', which is the typical EU level form of delegated legislation (see below).
} 
initial stage of new policy initiatives, generally in the context of an online consultation, ${ }^{35}$ and sometimes combined with the drafting of an impact assessment. ${ }^{36}$

Based on this analysis of the Principles and Standards, two especially significant gaps in the regulation of interest representation emerge. First, the Communication is focused on the initial stages of policymaking and participation in delegated legislation remains, for the most part, a black box. Second, the system of advisory committees described earlier in this chapter has been largely untouched. The Communication states that 'where a formal or structured consultation body exists, the Commission should take steps to ensure its composition properly reflects the sector it represents' (p.20, emphasis added). The Communication, however, fails to provide instruments and criteria for ensuring the representative composition of existing consultation bodies and to the extent that balance is not achieved it instructs the Commission to 'consider how to ensure that all interests are being taken into account (e.g. through other forms of consultation)'. Here we see the principal strategy employed in the 2002 Communication: it seeks to improve interest group participation by creating an additional form of consultation (i.e. open or targeted online consultation), not by reforming the multiple, existing mechanism of interest group consultation.

\section{Towards more proceduralisation and American-style pluralism?}

Over the past decade, there have been three major developments that have the potential to move the EU towards a system of interest group intermediation closer to the American pluralist model: the changes introduced by the Lisbon Treaty, the better regulation debate, and the Transparency Initiative. The following section carefully analyzes each of these recent additions to the EU's institutional framework and concludes that, on balance, the European system of interest representation remains one of pluralisation without (hard) proceduralisation.

\subsection{The Lisbon Treaty}

\footnotetext{
${ }^{35}$ On the Commission's Transparency website, the Communication is linked to 'Your Voice in Europe', the website for Commission online consultations, but not to the Register of Expert Groups, or the Comitology Register. See http://ec.europa.eu/transparency/index_en.htm (last accessed on: $15 / 11 / 12)$.

${ }^{36}$ The reader should note, however, that online consultations and impact assessments are not always conducted in tandem or for the same policy initiatives (see below).
} 


\subsubsection{Article 11 TFEU: constitutionalising participatory democracy?}

At the constitutional level, there has been one particularly visible change with ramifications for interest group participation. The Lisbon Treaty, which entered into force in 2009, amended the Treaty on European Union (TEU) to include the title 'Provisions on Democratic Principles'. After first establishing in Article 10 TEU that the Union is based on the principle of representative democracy, Article 11 TEU lists various types of other participatory procedures. In its original version (in the failed Constitutional Treaty) Article 11 TEU was entitled 'participatory democracy'. This term and concept were deleted from the final version, but the substance of the article has remained the same, and reads as follows:

1. The institutions shall, by appropriate means, give citizens and representative associations the opportunity to make known and publicly exchange their views in all areas of Union action.

2. The institutions shall maintain an open, transparent and regular dialogue with representative associations and civil society.

3. The European Commission shall carry out broad consultations with parties concerned in order to ensure that the Union's actions are coherent and transparent.

4. Not less than one million citizens who are nationals of a significant number of Member States may take the initiative of inviting the European Commission, within the framework of its powers, to submit any appropriate proposal on matters where citizens consider that a legal act of the Union is required for the purpose of implementing the Treaties...

Article 11 TEU was the product of an effort to constitutionally recognize the importance of participatory procedures other than electoral participation, something which the Commission in particular had stressed ever since the publication of the White Paper on European Governance. During the drafting process, the scope of participatory procedures was broadened to include not only 'civil society' or interest groups, but also a 'citizens' initiative,' since it was argued that the debate had been too narrowly focused and that the democratic process should also, or even above all, ensure that citizens could participate directly in policy-making. ${ }^{37}$ The introduction of the 'citizens' initiative' procedure (para.4), which allows a minimum of one million citizens to invite the

\footnotetext{
${ }^{37}$ For details on the debate among the governments and elected representatives during the drafting process, see Smismans (2004).
} 
European Commission to take action is therefore the most innovative part of Article 11 TEU, although its effect is likely to be limited (as illustrated by its practice until now). ${ }^{38}$ The first three paragraphs, by contrast, seem mainly to confirm existing institutional practices of state-society relations. The formulation is vague and the intent behind the use of the different concepts of 'representative associations', 'civil society' and 'parties concerned' is unclear. The Article neither introduces new procedures for interest group participation nor introduces participatory rights enforceable in court. It is highly unlikely that the European Court of Justice could ever sanction the Institutions for not respecting Article 11 TEU, except for the rare and fairly implausible scenario in which the Institutions do not provide for any form of participation at all. Nevertheless, Article 11 TEU may serve as instrument for the soft proceduralisation of interest intermediation. In the future, the Court, and especially the Institutions themselves, may rely on Article 11 TEU together with other (mainly soft) procedural requirements to underscore the importance of participation for the policy-making process and may thereby contribute to a culture in which the failure to establish and follow participatory procedures is perceived by politicians and officials as breaching institutional expectations. In this respect, the reference in paragraph 2 to all institutions is particularly important, since until now only the Commission has consistently paid attention to participatory procedures.

\subsubsection{Participation in the new system of delegated legislation and comitology}

While not as cleary related to the topic of interest group participation, another important reform introduced by the Lisbon Treaty deserves our attention, namely the new system of delegated legislation. The European system of delegated legislation has traditionally functioned via so-called 'comitology', whereby the legislator (the European Parliament and the Council on the initiative of the Commission) delegates to the Commission the task of adopting further regulatory measures. The Commission, however, is required to do so in interaction with a 'comitology committee', composed of representatives of all the Member States, generally drawn from the national

\footnotetext{
${ }^{38}$ The experience with citizens' initiatives to date suggests that it is difficult for the signatures of such a relatively low number of citizens (one million) to force substantial changes to a regulatory framework that has been carefully crafted by the democratically representative institutions of the European Parliament (through direct election of the members of parliament) and the Council (through the Member States), generally after broad consultation with stakeholders and experts. See Smismans (forthcoming).
} 
authorities dealing with the particular policy area at issue. This system is designed to allow the Member States to retain some degree of control over policy-making even after powers are delegated to the supranational European Commission. Although the intricacies of comitology are beyond the scope of this chapter, for purposes of the analysis here it is important to note that neither the political nor the academic debate has paid much attention to the issue of interest group participation in comitology. That is not to say that there is no such participation. Advisory or expert groups (as described above) are not only active in legislative procedures but also in comitology procedures, often operating alongside comitology committees, and the issues raised in delegated legislation are sometimes the target of lobbying before the Commission and even directly before comitology committees. At least to an American audience, it may come as a surprise that in the EU interest group participation has been extensively debated in the context of legislative action, but not delegated legislation and the comitology procedure.

The debate on comitology that emerged during the drafting of the Lisbon Treaty afforded a political opportunity to consider the role of participatory procedures in delegated legislation. This opportunity, however, was missed and, as in the previous two decades, the focus was on the place of the European Parliament in delegated legislation. From the perspective of the Parliament, delegated legislation is problematic because, unlike the Member States which can exert some control via comitology committees, the Parliament has traditionally had no role in delegated legislation. Although reforms made in the 1990 s opened the door to some parliamentary involvement, ${ }^{39}$ they fell short of expectations, especially in view of the Parliament's enhanced powers over legislation. The solution in the Lisbon Treaty was to introduce a distinction between 'legislative acts', 'delegated acts' and 'implementing acts'. While the material scope of these types of acts is poorly defined, ${ }^{40}$ and has been strongly criticised in the literature (Schutze 2011), ${ }^{41}$ the

\footnotetext{
${ }^{39}$ Council Decision 1999/468 laying down the procedures for the exercise of implementing powers conferred on the Commission, OJ 1999 L 184/23; and Council Decision 2006/512 amending Decision 1999/468, OJ 2006 L200/11.

${ }^{40}$ This, together with the fact that the categories of Regulation, Directive and Decision continue to exist, means that the objective of a clearer hierarchy of norms can hardly be considered to have been realised. There are now potentially nine types of instruments that can be adopted under the TEU: Legislative Regulations, Directives and Decisions; Delegated Regulations, Directives and Decisions; and potentially Implementing Regulations, Directives and Decisions.
} 
normative aspiration behind the text was to create a hierarchy of norms that would correspond with the appropriate level of parliamentary involvement. The most important norms are to be set down in legislative acts adopted by the legislator (the Parliament and the Council on initiative of the Commission), acts of general application 'supplementing or amending certain non-essential elements of a legislative act' (Article 190 TFEU) are to be adopted in delegated acts, by the Commission under the control of the Parliament and the Council, and executive implementing acts are primarily the responsibility of the Commission. Delegated acts are to be controlled equally by the Parliament and the Council: either the Parliament or Council may revoke the delegation; or they may object to a delegated act within a period set out by the legislative act. ${ }^{42}$ Implementing acts continue to be adopted through a system of comitology, leaving control of the Commission in the hands of the Member States, with virtually no involvement of the Parliament.

In these changes wrought by the Lisbon Treaty, the Parliament was the winner, since it obtained considerably more control power over delegated acts, while the Member States saw their powers diminished somewhat since comitology committees were eliminated for delegated acts. Yet the provision on delegated acts was also a missed opportunity. At the time of the drafting of this new hierarchy of norms, I argued that the new distinction may open the way for the reconsideration of the role of proceduralisation of participatory processes (Smismans 2005). Since the experience of other democracies suggests that legislative vetoes are a very blunt instrument of control that are rarely used (Schutze 2011: 664), I argued that participatory procedures offered an additional mechanism for holding the administration accountable. Interest group participation, however, never entered into the debate during the drafting of the Lisbon Treaty (or its forerunner, the Constitutional Treaty). For both the Member States and many Members of Parliament, the arcane topic of comitology appeared difficult enough to understand, even without including the topic of interest group participation.

The adoption of the Lisbon Treaty did not end the debates over delegated acts and implementing acts. In 2011, the Parliament and Council adopted a new legislative framework for comitology in implementing acts and, somewhat surprisingly, this legislative framework actually reduced the Parliament's powers, as it no longer has a right of scrutiny over the resulting implementing acts

\footnotetext{
${ }^{41}$ As Hofmann (2009: 499) puts it: 'The opaqueness of EU law has been deliberately taken to a new level in order to make an abstract theoretical point of typology to press the EU into a state-like federal model'.

${ }^{42}$ It is up to the delegating legislation to choose between these two control mechanisms.
} 
(Christiansen and Dobbels 2012). ${ }^{43}$ At the same time, the Member States fought back to regain power over delegated acts. While Article 190 TFEU does not provide for comitology in the case of delegated acts and the Commission has refused to create comitology committees with formal powers, the Member States have obtained a political commitment from the Commission to consult with Member State representatives (Christiansen and Dobbels 2012: 17). This has been set down in a non-binding 'Common Understanding' signed by the Commission, Council, and Parliament: when drafting delegated acts, the Commission agrees to conduct consultations with the Council and the Parliament, and to send both institutions all the relevant preparatory documents, while at the same time retaining discretion over how to organise such consultations. ${ }^{44}$

To conclude this discussion of the Lisbon Treaty, the outcome from the perspective of participatory procedure was disappointing overall. Instead of a transparent system of control over delegated acts based, on the one hand, on the legislative veto and, on the other hand, the proceduralised participation of interest groups, the end result was a system of protracted Member State control behind the scenes. Although interest groups certainly exercise influence through lobbying, this remains largely unregulated and outside of the public eye. The latter can equally be said of the new system of comitology under the new Comitology Regulation of 2011, which applies to implementing acts, and has left the (non) regulation of interest group participation in these procedures completely untouched. In sum, despite the intense debates spanning over a decade, the role of interest group participation in the EU's system of delegated legislation remains inside a black box; as we will see in the next section, the debate on better regulation might just provide some opportunity to open the black box.

\subsection{The better regulation debate}

The better regulation debate began with the 2000 Lisbon Strategy to make the EU the 'most competitive knowledge-based economy in the world.' Like elsewhere, 'better regulation' has meant

\footnotetext{
${ }^{43}$ European Union (2011) 'Regulation (EU) No 182/2011 of the European Parliament and of the Council of 16 February 2011 laying down the rules and general principles concerning mechanisms for control by Member States of the Commission's exercise of implementing powers', Official Journal of the European Union, L 55/12, Brussels, 28.2.2011.

${ }^{44}$ Council of the European Union, Common Understanding - Delegated Acts, 8753/11, 11 April 2011.
} 
to a great extent 'less regulation', as the focus has been on reducing the regulatory burden on the market. In the EU, however, with its constant search for greater legitimacy, better regulation also became related to arguments about participation in policy-making. This was particularly the case around the time of the White Paper on European Governance (2001). Two 'participation topics' in particular entered the better regulation debate, namely the importance of consultation during impact assessments $(\mathrm{IA})$ and the need to reflect on alternative regulatory instruments via coregulation and self-regulation. ${ }^{45}$ I focus here on the former.

Since 2003, IAs have been routinely issued by the Commission. The Commission drafts IAs for all major policy proposals, i.e. mainly legislative proposals but also policy programmes and key communications. The EU's impact assessment system is characterised by a broad 'integrated approach', which includes an assessment of economic, social and environmental impacts. To realise such an integrated approach, the involvement of all relevant stakeholders is essential. The 2009 Commission Guidelines on IAs identify three essential variants of sound evidence for IAs, namely 'internal expertise' (i.e. available in Commission Directorates General other than the one drafting the IA), 'external expertise' (i.e. drawn from expert committees, European agencies, and independent experts), and 'consultation with interested parties'.

In theory, IA could serve as a vehicle for the proceduralisation of interest representation, similar to notice-and-comment rulemaking in the United States. In such a system, if the Commission in conducting an IA failed to consult the public or consulted but entirely discarded the opinions expressed by the public, the final outcome could be challenged in court. However, the European system allows, at best, for only a very soft form of proceduralisation. To begin with, the procedural rules for IAs are set out in Guidelines, i.e. a soft law instrument not directly justiciable in court. Although the European Court of Justice has recognised that the Commission may create legitimate expectations enforceable in court by promising administrative behaviour through such soft law documents, it is unlikely that Court would find that the Guidelines on IAs give rise to a legitimate expectation of stakeholder participation since they afford the Commission with considerable leeway. According to the Guidelines, IAs are based on the principle of 'proportionate analysis', which also extends to how participation is organised: it is for the Commission to decide how to organise participation 'proportionate to' the importance and scope of an initiative. Most importantly, the Guidelines do not set out any specific procedure for stakeholder involvement-whether through advisory committees, online consultations, or informal contacts. They do state that the Commission

${ }^{45}$ European Parliament, Council and Commission, Interinstitutional Agreement on Better LawMaking OJ 2003/C, 321/01. 
should respect the 2002 Principles and Standards of Consultation but, as analysed above, these Principles and Standards are notoriously flexible. Therefore, even though it is correct that the information included in IAs may inform the Court's application of substantive review principles such as subsidiarity and proportionality (Alemanno 2011) it is unlikely that the very vague standards for consultations on IAs will give rise to a new ground of review based on the violation of a procedural requirement.

Even though the role for courts is limited, a softer form of proceduralisation of IAs may emerge in the future. All IAs are screened by the European Impact Assessment Board (IAB), which is a body composed of senior officials within the European Commission. If the IAB considers that an IA does not respect the IA Guidelines, the IA will be sent back for readjustment to the Directorate General which drafted it. It is the task of the IAB to strike the fine balance between leaving the DGs flexibility, in line with the principle of proportionate analysis, and establishing a common practice with minimum standards applicable to all IAs. This is equally the case for issues of participation within the IA procedure. To date, the IAB has mainly insisted that when the Commission decides to hold a consultation, the responsible DG should make more of an effort to ensure that stakeholder views are represented throughout the entire IA, in particular on all the policy options proposed in the IA. ${ }^{46}$ In theory, however, the IAB could become more demanding with participation requirements. For instance, some DGs publish all individual opinions of stakeholders with the IA, while others only provide a synthesis of the opinions. Some DGs, when sending an IA to the other Institutions attach all the opinions, others attach an overview, and yet others also publish the opinions or the overview online. The IAB could develop a common approach on this and other elements of the consultation procedure. It could go even further and require DGs to reflect and report on the representativeness of their consultation procedures, in line with the soft guidelines provided in the 2002 Principles and Standards of Communication. It is unlikely, however, that the $I A B$ will take this step, since participation has never been a key priority for the Board, and it has become especially less so in recent years as the better regulation agenda has become focused more on competitiveness and less on improving legitimacy through participation (Radaelli 2007:194).

One area currently in flux is the role of IAs in delegated legislation and comitology. As explained earlier and in contrast with the U.S., IAs have traditionally been used for major policy initiatives, i.e. legislation, and not for classic administrative rules (see Weiner and Ribero in this volume). In 2009, for the first time, the Commission recognized that IAs could also be used for delegated legislation

\footnotetext{
${ }^{46}$ This conclusion is based on an analysis of 20 IAs (in different policy fields) as well as the annual IAB reports as part of the LASI project. See above footnote 1.
} 
and comitology. ${ }^{47}$ As was argued above in discussing the treatment of delegated legislation in the Lisbon Treaty, this represents a positive development with the potential to shed light on the currently opaque system of interest group participation at the implementing phase of the policymaking process. The reality, however, is still quite limited. The number of IAs in delegated legislation and comitology is still very low. ${ }^{48}$ Moreover, it remains to be seen what type of consultations, if any, will be held in the context of such IAs: since both the content and procedure of IAs are to be "proportionate" to the nature of the proposal, which in the case of delegated acts and implementing acts can be expected to be less significant, and since IAs for delegated and implementing acts are to avoid re-considering issues that were already assessed in the context of the legislative act, any consultation that is held might very well be quite cursory (Alemanno and Meuwese 2013; Mendes 2013).

Before leaving the subject of IAs, it bears asking if and how this layer of procedure departs from the patterns of interest representation established by the other participation procedures and institutions discussed earlier in this chapter. Although the experience in this field is still quite new, several preliminary conclusions can be drawn from research conducted in the context of the LASI project. ${ }^{49}$ We assessed all IAs adopted between 2003 and 2013 (830 in total) on the basis of the information on participation provided by the IA reports (which always include a section with information on the actors consulted). Despite the discursive insistence on the importance of broad stakeholder participation, IAs do not appear to have led to a general pluralisation of the consultation procedure. Although IAs have increasingly come to use general online consultations, they remain the exception rather than the rule, and represent only $25 \%$ of all IAs. In addition to any online consultation procedure, the Directorate General responsible for preparing an IA will involve, on average, 10.3 actors, which can include Commission DGs, European expert committees or agencies, interest groups, and consultancies. Although it is necessary to investigate further how IAs may or may not have changed established patterns of participation through advisory committees or via informal lobbying, our data support the conclusion that IAs have not significantly expanded the number or types of actors consulted by the Commission and consequently have not produced a general pluralisation of interest group participation in rulemaking.

\footnotetext{
${ }^{47} 2009$ Guidelines, supra at _.

48 In the period 2009-2013, 3 IAs were adopted for delegated acts, and 21 for implementing acts.

${ }^{49}$ LASI is an ERC funded research project dealing with 'Law, science and interests in European policymaking'. (see footnote 1). I would like to thank my colleague Dr Emanuela Bozzini for the statistical analysis. For a more detailed treatment of the argument, see Bozzini and Smismans (forthcoming).
} 


\subsection{The transparency debate}

In 2006 the European Commission launched the European Transparency Initiative (ETI). ${ }^{50}$, The main objective of the ETI was not to shape interest group participation but to make it more transparent. In addition to providing an online list of beneficiaries of EU funding, ${ }^{51}$ the key innovation has been the introduction of a 'Transparency Register' - an online register of lobbyists applicable to both the European Commission and the European Parliament which replaces the CONECCS database discussed earlier. ${ }^{52}$ Unlike CONECCS, which only listed European civil society organisations as part of the effort to incentivize more representative organisations, the Transparency Register aims to include all types of lobbying actors, whether NGOs, think-tanks, academic institutions, in-house lobbyists or consultancies. Compared to CONECCS, it also records more information on lobbying actors, in particular regarding their financial resources. At the same time, the organizations that register are required to sign a code of conduct on good lobbying practices.

At first sight, the Transparency Initiative is inspired by the pluralist tradition, but a closer look reveals it may be used in a way closer to the neo-corporatist tradition discussed earlier. On the one hand, the Register promotes free competition among interest groups to influence policy-making by ensuring that the process is transparent and that the actors follow minimum standards of ethical lobbying behaviour. Although the Register is not obligatory, estimates suggest that about three quarters of EU-level lobbying actors are now registered, thanks to a system of persuasion, naming and shaming, and carrots rather than sticks, such as an early-alert email system for new consultations. ${ }^{53}$ On the other hand, it does not create any new procedural rights to influence

\footnotetext{
${ }^{50} \mathrm{COM}(2006) 194$ final.

${ }^{51}$ See http://ec.europa.eu/budget/fts/index_en.htm, last access on 20/08/14.

${ }^{52}$ Communication Follow-up to the Green Paper "European Transparency Initiative" COM(2007)127 final; Communication European Transparency Initiative: A framework for relations with interest representatives (Register and Code of Conduct) COM(2008)323 final; Agreement between the European Parliament and the European Commission on the establishment of a transparency register for organisations and self-employed individuals engaged in EU policy-making and policy implementation, [2011] OJ L191/29.

${ }^{53}$ These are estimates as it is difficult to identify the exact number of actors involved in EU lobbying. See Greenwood and Dreger (2013).
} 
government decision making, as found in the pluralist American system of notice-and-comment rulemaking. Moreover, as a result of the Transparency Register, the Commission and the European Parliament now have at their disposal considerably more information on lobbying actors, which can be used to determine whether organizations and groups are representative and can help achieve balanced interest representation on advisory committees. ${ }^{54}$ The Register would thus function as a tool within a neo-corporatist setting.

\section{Conclusion}

Interest group participation in the European Union has evolved considerably since the creation of the European Economic Community in 1957. As the powers of the EU increased, interest groups shifted their attention to the European level, formed European 'umbrella organisations', and often set up offices in Brussels. At the same time, broader societal forces produced new social movements, a proliferation of functional categories, and considerable pluralisation of interest groups. In response, the EU has opened its policy-making process to a variety of interest groups. The multiple access points for interest group influence-through the Commission, the European Parliament, and national representatives in the Council-has also led many observers to describe the EU as a pluralist system of interest intermediation. At the same time, the EU's institutions have been shaped by the neo-corporatist legacy that characterises many of its Member States. Thus the system of interest intermediation traditionally contained two parallel strands: on the one hand, extensive, informal lobbying and, on the other hand, formal advisory committees as way for the public administration (principally the Commission) to ensure, at least in theory, balanced interest representation in policy-making.

From a comparative perspective, especially for those familiar with the American neo-pluralist model of interest representation, there are two striking elements of the European system. First, legally binding participation rights and procedures that can be enforced in court are largely absent. Although there are minor exceptions to this rule, ${ }^{55}$ most participatory processes are entirely informal or are set down in soft law documents which provide virtually no scope for judicial review. Second,

\footnotetext{
${ }^{54}$ For a more detailed analysis of this argument, see Smismans (2014).

${ }^{55}$ The primary ones are in the area of state aid policy, see Mendes (2011), and in those cases where legislation requires the consultation of an advisory committee and the Commission entirely fails to consult the committee (an extremely remote scenario).
} 
to the extent that the political debate has considered interest group participation, the focus has been on participation in legislative decision-making, not delegated legislation (or rulemaking in American legal terminology). This can be explained by the EU's (perceived) lack of legitimacy: in the 1990s and 2000s repeated attempts at EU institutional reform have sought to address the concern that EU decision-making is removed from the concerns of its citizens and improving participation before the Commission, when it drafts legislation, represents one such effort at democratic innovation. It must be said, however, that the silence on participation and delegated legislation remains remarkable.

Over the last two decades the EU has attempted to formalise somewhat its relations with interest groups. Above all, the system has become more transparent with the Register of Expert Groups on advisory committees and the Transparency Register on lobbying organizations. Since the end of the 1990s, and particularly since the White Paper on European Governance, the EU also has attempted to make its system of interest intermediation more 'representative' or 'balanced'. However, instead of reforming the existing system, in particular advisory committees, the Commission has mainly inserted the additional step of a broad-based online consultation at the start of the (legislative) policy-making process - pluralising the system by adding another participation layer.

Although more recent efforts at reform, such as the better regulation debate and the Transparency Initiative, have clearly been inspired by American regulatory law and practice, the European system of interest group participation continues to be shaped by its neo-corporatist legacy and is best conceptualized as 'institutionalised but not proceduralised'. There is no sign that European political and administrative elites have any intention of pursuing such a strongly proceduralised route, at least in the foreseeable future. Neither would I argue that such route would be preferable. The European institutional tradition tends to rely on the administration to ensure that policy-making is informed by a balanced representation of interests, while the American one places more trust in market-style free competition between interest groups to achieve fair representation. Evidence on both sides of the Atlantic shows that policy-making is biased in favour of corporate and business interests and against broader societal interests. The jury is still out on whether either of the two systems is 'more effective' or 'fairer', and any judgment will inevitably reflect, at least in part, normative attitudes towards the state and interest groups more broadly speaking. For the moment, despite the discourse in American law of formal equality and procedural rights, on the European side of the Atlantic the perception is that for all of its imperfections, a system that relies less on courts and more on administrative and political actors to remedy imbalances in representation is fairer overall. 


\section{References}

Alemanno, Alberto. 2011. "A Meeting of Minds on Impact Assessment: When Ex Ante Evaluation Meets Ex Post Judicial Control," 17 European Public Law 485-505.

Alemanno, Alberto and Anne Meuwese. 2013. "Impact Assessment of EU Non-Legislative Rulemaking: The Missing Link in 'New Comitology," 19 European Law Journal 76-92.

Barnard, Catherine. 1995. “A European Litigation Strategy: The Case of the Equal Opportunities Commission," in Jo Shaw and Gillian More, eds., New Legal Dynamics of European Union. Oxford: Clarendon Press, 253-275.

Bignami, Francesca. 2011. "From Expert Administration to Accountability Network: A New Paradigm for Comparative Administrative Law," 59 American Journal of Comparative Law 859-907.

Bohman, James and William Rehg, eds. 1997. Deliberative Democracy: Essays on Reason and Politics. Cambridge, Mass.: MIT Press.

Bozzini, Emanuela and Stijn Smismans. Forthcoming. "More inclusive governance in the EU through impact assessments?," Comparative European Politics.

Busuioc, Madalina, Martijn Groenleer and Jarle Trondal, eds. 2012. The Agency Phenomenon in the European Union: Emergence, institutionalisation and everyday decision-making. Manchester: Manchester University Press.

Cawson, Alan. 1986. Corporatism and Political Theory. Oxford: Blackwell Publishers.

Christiansen, Thomas and Mathias Dobbels. 2012. "Comitology and delegated acts after Lisbon: How the European Parliament lost the implementation game," 16 Article 13 European Integration online Papers (EloP).

Cichowski, Rachel A. 2007. The European Court and Civil Society: Litigation, Mobilization and Governance, Cambridge: Cambridge University Press. 
Cohen, Joshua and Joel Rogers. 1995. "Secondary Associations and Democratic Governance," in Joshua Cohen and Joel Rogers, eds., Associations and Democracy. The Real Utopias Project. London: Verso, 7-98.

Corbey, Dorette. 1996. "Gezien het advies van het Economisch en Sociaal Comité. Economische democratie binnen de Europese Unie," 50 Internationale Spectator 344-348.

Craig, Paul. 1990. Public Law and Democracy in the United Kingdom and the United States of America. Oxford: Clarendon Press.

Crouch, Colin. 1994. Industrial Relations and European State Traditions. Oxford: Oxford University Press.

Dahl, Robert. 1956. A Preface to Democratic Theory. Chicago: University of Chicago Press.

Dahl, Robert. 2005. Who Governs? Democracy and Power in an American City. New Haven: Yale University Press.

Davis, Kenneth Culp. 1969. Discretionary Justice: A Preliminary Inquiry. Urbania: Louisiana State University.

De Schutter, Olivier. 2006. "Group Litigation before the European Court of Justice," in Stijn Smismans, ed., Civil Society and Legitimate European Governance. Cheltenham: Edward Elgar, 89114.

Dryzek, John S. 2000. Deliberative Democracy and Beyond: Liberals, Critics, Contestations. Oxford: Oxford University Press.

Ebbinghaus, Bernhard and Philip Manow. 2001. Comparing Welfare Capitalism: Social Policy and Political Economy in Europe, Japan and the USA. London: Routledge.

Eising, Rainer. 2008. "Interest groups in EU policy-making," 3 Living Reviews in European Governance. Available at www.livingreviews.org/lreg-2008-4 (last accessed on: 10/09/14). 
Elster, Jon, ed. 1998. Deliberative Democracy. Cambridge: Cambridge University Press.

Esping-Andersen, Gøsta. 1990. Three Worlds of Welfare Capitalism. Princeton: Princeton University Press.

European Foundation for Living and Working Conditions. 2013. Impact of the Crisis on Industrial Relations. Available at http://www.eurofound.europa.eu/eiro/studies/tn1301019s/index.htm (last accessed on: 10/09/14

***European Trade Union Institute. 1990. The Role of Economic and Social Councils in Western Europe. Brussels: E.T.U.I.

Everson, Michelle and Christian Joerges. 2006. "Re-conceptualising Europeanisation as a public law of collissions: comitology, agencies and an interactive public adjudication," in Herwig Hofman and Alexander Turk, eds., EU Administrative Governance. Edward Elgar: Cheltenham, 512-540.

Featherstone, Kevin. 1994. "Jean Monnet and the "Democratic Deficit," in the European Union," 32 Journal of Common Market Studies 149-170.

Finke, Barbara. 2007. "Civil society participation in EU governance," 2 Living Reviews in European Governance. Available at http://europeangovernance.livingreviews.org/Articles/Ireg-2007-2/ (last accessed on10/09/14).

Gerstenberg, Oliver and Charles F. Sabel. 2002. “Directly-Deliberative Polyarchy: An Institutional Ideal for Europe?," in Christian Joerges and Renaud Dehousse, eds., Good Governance in Europe's Integrated Market, Oxford: Oxford University Press, 289-341.

Glassner, Vera, Maarten Keune and Paul Marginson. 2011. "Collective Bargaining in a Time of Crisis: Developments in the Private Sector in Europe," 17 Transfer: European Review of Labour and Research 303-321.

Greenwood, Justin and Joanna Dreger. 2013. "The Transparency Register: A European Vanguard of Strong Lobbying Regulation?," 2 Interest Groups \& Advocacy 139-157. 
Habermas, Jürgen. 1996. Between Facts and Norms: Contributions to a Discourse Theory of Law and Democracy, tr. William Rehg. Cambridge, Mass.: MIT Press.

Harlow, Carol. 2006. "Civil society Organisations and Participatory Administration: a Challenge to EU Administrative Law?," in Stijn Smismans, ed., Civil Society and Legitimate European Governance. Cheltenham: Edward Elgar, 115-140.

Harlow, Carol and Richard Rawlings. 1992. Pressure Through Law. London: Routledge.

Carol, Harlow. 1992. "A Community of Interests? Making the most of European Law" 55 The Modern Law Review 331-350.

Held, David. 1996. Models of Democracy. $2^{\text {nd }}$ ed. Stanford: Stanford University Press.

Hofmann, Herwig. 2009. "Legislation, Delegation and Implementation under the Treaty of Lisbon: Typology Meets Reality," 15 European Law Journal 482-505.

Hyman, Richard. 2009. "Pluralism, Procedural Consensus and Collective Bargaining," 16 British Journal of Industrial Relations 16-40.

Hyman, Richard. 2010. "Social dialogue and industrial relations during the economic crisis: Innovative practices or business as usual?," Working Paper No. 11. Geneva: International Labour Office. Available at http://www.ilo.org/wcmsp5/groups/public/---ed_dialogue/--dialogue/documents/publication/wcms_158355.pdf.

Kagan, Robert A. 2007. "Globalization and legal change. The 'Americanization' of European Law?," 1 Regulation \& Governance 99-120.

Knoepfel, Peter and Ingrid Kissling-Näf. 1998. "Social Learning in Policy Networks," 26 Policy \& Politics 343-367(25).

Larsson, Torbjorn and Jan Murk. 2007. "The Commission's relations with Expert Advisory Groups," in Thomas Christiansen and Torbjorn Larsson, eds., The Role of Committees in the Policy-Process of the European Union: Legislation, Implementation and Deliberation. Edward Elgard: Cheltenham, 64-95. 
Lehmbruch, Gerhard and Philippe C. Schmitter. eds,. 1982. Patterns of Corporatist Policy-Making. London: Sage Publications.

Lodge, Juliet and Valentine Herman. 1980. "The Economic and Social Committee in EEC decisionmaking," 34 International Organisation, 265-284.

Lowi, Theodore. J. 1979. The End of Liberalism: The Second Republic of the United States. New York: W.W. Norton \& Co Inc..

Mahoney, Christine and Michael J. Beckstrand. 2011. "Following the Money: European Union Funding of Civil Society Organizations," 49 Journal of Common Market Studies 1339-1361.

McLaughlin, Diarmid. 1985. "The involvement of social partners at European level," in Jacques Vandamme, ed., New Dimensions in European Social Policy. London: Croom Helm, 155-173.

Mechi, Lorenzo. 2000. "Il Comitato Consultivo della CECA," in Antonio Varsori, ed., I/ Comitato Economico e Sociale nella costruzione europea. Venice: Marsilio, 34-46.

Mendes, Joana. 2011. Participation in EU Rule-making. A Rights-based Approach. Oxford: Oxford University Press.

Mendes, Joanna. 2013. "Delegated and Implementing Rule Making: Proceduralisation and Constitutional Design," 19 European Law Journal 22-41.

Micklitz, Hans-W and Norbert Reich, eds. 1996. Public Interest Litigation Before European Courts. Baden-Baden: Nomos.

Milward, Alan. 1992. The European Rescue of the Nation-State. London: Routledge.

Nedelmann, Birgitta and Kurt G. Meier. 1979. "Theories of Contemporary Corporatism. Static of Dynamic?," in Philippe. C. Schmitter and Gerhard Lehmbruch, Trends Toward Corporatist Intermediation. London: Sage, 95-118. 
Nino, Carlos Santiago. 1996. The Constitution of Deliberative Democracy. New Haven: Yale University Press.

Olson, Mancur. 1965. The Logic of Collective Action: Public Goods and the Theory of Groups, Cambridge, Mass.: Harvard University Press.

Pérez-Solórzano Borragán, Nieves and Stijn Smismans. 2012. "The European Union and Industrial Relations in the New Member States," in Stijn Smismans, ed. The European Union and Industrial Relations - New Procedures, New Context. Manchester: Manchester University Press, 116-138.

Radaelli, Claudio. 2007. "Whither better regulation for the Lisbon agenda?," 14 Journal of European Public Policy 190-207.

Rittberger, Berthold and Arndt Wonka. 2011. "Introduction: Agency governance in the European Union,"|18 Journal of European Public Policy 780-789

Sabel, Charles and Jonathan Zeitlin. 2008. "Learning from Difference: The New Architecture of Experimentalist Governance in the EU," 14 European Law Journal 271-327.

Schmidt, Vivien A. 1997. "European integration and democracy: the differences among member states," 4 Journal of European Public Policy 128-145.

Philippe C. Schmitter. 1974. "Still the Century of Corporatism?" The Review of Politics 85 - 131.

Schutze, Robert. 2011. “'Delegated' Legislation in the (new) European Union: A Constitutional Analysis," 74 Modern Law Review 661-693.

Shapiro, Martin. 1988. Who Guards the Guardians?: Judicial Control of Administration. London: The University of Georgia Press.

Smismans, Stijn. 2000. "The European Economic and Social Committee: towards deliberative democracy via a functional assembly," in 4 European Integration online Papers (EloP). Available at (http://eiop.or.at/eiop/texte/2000-012a.htm) (last accessed on 13/01/14). 
Smismans, Stijn. 2004. "The constitutional labelling of 'the democratic life of the EU': representative and participatory' democracy," in Andreas Follesdal and Lynn Dobson, eds., Political Theory and the European Constitution. London: Routledge, 122-138.

Smismans, Stijn. 2005. "The pluralistic deficit in EU Delegated Regulation: Lessons from the United States at the EU's 'Constitutional Momentt,” 12 Indiana Journal of Global Legal Studies 599-630.

Smismans, Stijn. 2008. "New Modes of Governance and the Participatory Myth," 31 West European Politics 874-895.

Smismans, Stijn ed. 2013. The European Union and Industrial Relations: New Procedures, New Context. Manchester: Manchester University Press.

Smismans, Stijn. 2014. "Regulating interest group participation in the European Union: Changing Paradigms between transparency and representation," 39 European Law Review 470-492.

Smismans, Stijn. Forthcoming. "Democratic participation and the search for an institutional architecture that accommodates interests and expertise," in Simona Piattoni, ed., The European Union: Democratic Principles and Institutional Architectures in Times of Crisis. Oxford: Oxford University Press.

Stewart, Richard B. 1975. "The Reformation of American Administrative Law," 88 Harvard Law Review 1667-1813.

Streeck, Wolfgang and Philippe C. Schmitter. 1991. "From National Corporatism to Transnational Pluralism: Organized Interests in the Single European Market," 19 Politics and Society 133-164.

Sunstein, Cass R.. 1985. "Interest Groups in American Public Law," 38 Stanford Law Review 29-87.

Truman, David B. 1951. The Governmental Process: Political Interest and Public Opinion. New York: Alfred A.Knopf. 
Van Gerven, Walter. 1996. "The Legal Dimension: The Constitutional Incentives for and Constraints on Bargained Administration," in Frances Snyder, ed., Constitutional Dimensions of European Economic Integration. The Hague: Kluwer Law International.

Wallace, Helen. 1993. "European Governance in Ibrbulent Times," 31 Journal of Common Market Studies 293-304.

Wallace, Helen. 1996. "The Institutions of the EU: Experience and Experiments," in Helen Wallace and William Wallace, eds., Policy-making in the European Union. Oxford: Oxford University Press, 3768.

Williamson, Peter J. 1989. Corporatism in Perspective: An Introductory Guide to Corporatist Theory, London: Sage Publications. 